\title{
In Trail of the Clash of two Civilizations
}

\author{
Rashmi Sirohi \\ Guru Gobind Singh Indraprastha University \\ New Delhi, India \\ sirohirashmi92@gmail.com
}

\begin{abstract}
Nature is full of mysteries which compel one to explore the hidden passages. The passionate urge might take a traveller into the deepest corners of forgotten lands which have truths to be unraveled. Each and every space dynamics has its own temporality and ideological framework which shapes the entire course of ones ideas. The paper will talk about the travelling account of Che Guevara captured in his memoir The Motorcycle Diaries. The book traces the early travels of this Marxist revolutionary. The idea behind is to mark the curvature of topological transformation and its impact on the ideological framework of a person. The paper will explore the interconnections and impact of different spaces encountered during a travel and the nature of discourse which develops during such explorations. Ideas have a disposition to travel with the moving discourse where the architectural domain shapes the outline of the traveller's thought process. Here Che Guevara's trip through South America will portray the flow of ideas through different spaces formulating the base for his revolutionary ideas. Through the account of Francisco Pizarro during the conquest of Incan civilization and through the impact of this event on the civilization as a collective whole, the paper will attempt to analyze the ethical curvature of two distinct civilizations, namely the Incan and the Christian Imperial West. The conquest of the South American continent and the consequent clash was cataclysmic, as the socio-economic subversion is still embedded almost
\end{abstract}


non- retrievably deep in terms of its collateral. The paper will include "Heights of Machu Picchu" by Pablo Neruda which again is set during his travelling account to Machu Picchu, which is the marker of a lost civilization where the distorted architecture echoes the richness and the loss at the same time.

Keywords- journey, travel, collectivity, clash of civilizations, architectural spaces

Any form of expression is a journey between the absolute truth and the truth which is unconquerable. The unattainable can never be attained which is why a journey never ends. A painter is forever on a journey to fill the gap through the expressions via colors, blankness and forms. The curvature of journey is non-linear which is why it is a pursuit not an enclosed, determined travel. The cognition of painter embarks on a journey towards the improbable, towards the unknown sublime. Here the medium of expression becomes the meeting point. It serves as a bridge between the two. The poetry of Neruda has unfathomable depths; an expanse which cannot be measured thus, never seeks finality. A journey in similar sense never reaches finality, it represents continuation. The movement of stars in Starry Night by Van Gogh seems as if the strokes are on a journey and at the same time it paints the picture in continuation making the painting of the beyond visible. It not only creates a linearly moving image but captures the velocity, the flow of the cosmos.

When a man has an urge to explore nature and its contours, the journey begins with the quest to visit its depth.Che Guevara puts forward his travelling account in his memoir "The Motorcycle Diaries". The book traces the early travel of this Marxist revolutionary to South American continent. His journey extends from Argentina to United States via Chile and Peru. Along his passage of journey he encounters various places which had a tremendous influence on his personality. Every space has its own dynamics which shapes the ideological frame of a person. The attempt of this paper is to explore the interconnections and impact of 
different spaces encountered during a 'travel' and the nature of discourse which develops during such explorations. Ideas have a disposition to travel with the moving discourse where the architectural domain shapes the outline of the traveller's thought process. Here Che Guevara's trip through South America portrays the flow of ideas through different spaces formulating the base for his revolutionary being.

A travel occurs between two terminal points from start to end and ultimately it is all about meeting those ends. When the ordered state of travel with its mapping and interactions with the architectural places ignite a disordered state of affair in the state of being, there begins the journey. Travel is sequential, traceable and linear with individualistic categorization whereas journey is non-sequential, non-traceable and non-linear with a sense of collectiveness. Journey cannot be located or recorded where travel becomes a starting point for journey. As a sublime painting like Starry Night by Van Gough traces a cluster of the stars but it moves beyond the frame when it touches upon the velocity. Frame or shape is necessary for the painting to exist but the form of the painting lies the abstraction where there is a propensity to create more shapes and frames. Travelogue signifies order, frame or shape which serves as the beginning for the journey to take flight which is disordered. The order and the disorder co-exist of which Friedrich Nietzsche has extensively talked about in his The Birth of Tragedy where he places the contradictory forces of order and disorder together in the context of tragedy but not limited to tragedy. His philosophical contestation of order and disorder is inclusive enough to be read universally.

In The Birth of Tragedy, Nietzsche has talked extensively about the co-existence of the opposites. He described two different tendencies of tragic art namely Apollonian and Dionysian. The two artistic worlds have different tendencies and connotations with the help of which Nietzsche has tried to dive into the massive pool of nature and its unknown complexities. He calls Apollonian tendency as an artistic world of dream and he says 
The seductive illusion of dream worlds, which every man is an accomplished artist in creating, is the precondition of any kind of visual art and of an important body of poetry. We take great pleasure in the sensual proximity of form, where all shapes speak to us, and nothing is listless or unnecessary. Nevertheless, even when this dream reality is manifested before us at the greatest pitch of intensity, we hold onto the impression, flitting in and out of consciousness, that it is still an illusion (68)

Nietzsche has placed the forms of aesthetics in terms of order and disorder, Apollonian and Dionysian, in order to deal with the gap between the known and perceptible to human eye of comprehension and the unknown and incomprehensible but which shows up in the hour of loss of form and shape. He takes about this peeking into the Dionysian artistic world while quoting Schopenhauer and he says

The surging dread that washes over man when, all of a sudden, he loses his way among the cognitive forms of appearance, because the principle of sufficient reason, in some form or other, appears to have become unhinged. If we add to this panic the dreadful, blissful ecstasy awakened by this fragmentation of the principium individuationis (principle of individuation), which rises up from man's innermost core, which rises up from within nature itself, we are permitted a glimpse into the nature of the Dionysian (69)

The subjectivity of a person in Dionysian world becomes a complete forgetting of the self. He talks of the primal unity where the artist's subjectivity is lost in the dream illusion of the reality and the artist leads onto the pure contemplation of images. This primal unity comes in the form of art, art form which has higher degree of randomness and is aesthetically formless such as music, painting and tragedy. In this primal unity the artist is merged with the "pain and disjunction" (Nietzsche 70) and he says 
under the influence of the Apollonian dream, this music is revealed to him as an allegory- a dream image. The reflection of ecstatic pain in sound, free of images and concepts, moderated by illusion, goes on to create a second mirror image as a single allegory, or example. The artist abandons his subjectivity in the Dionysian process. (70)

Aesthetically, beauty and truth are the components which are a function of order and disorder, Apollonian and Dionysian. Beauty and truth do not lie either in order or in disorder rather it lies in the sense of balance between the order and disorder. They do not fall on one side of the binary rather they become the tool to dissolve the binaries and it depends upon the capability of the art and the artist to create aesthetics which showcases the co-existence of the opposites. Nietzsche in The Birth of Tragedy says

Apollo appears to us as the apotheosis of the principumindividuationis. Apollo, considered as an ethical god, commands moderation from his followers, coupled with self-knowledge in order to maintain it. Thus the admonitions "know thyself" and "nothing to excess" coexist with the aesthetic necessity of beauty; while, on the other hand, hubris and excess are considered to be malign spirits of the extra-Apollonian realm; qualities of the age of the Titans, of the world of the barbarians. (73)

Without order Dionysian has no meaning and without disorder Apollonian cannot exist with sublimity. It is with the co-existence of the two contradictory senses that the aesthetics is evolved and the consciousness is developed. The illogical logic of the truth, the irrational rationality of the beauty, and the purposelessness of the purpose make a balance between the contradictions which is not like an assumed equilibrium rather a contestation. Nietzsche says that "Apollo could not live without Dionysus" (73). He further adds on to explain this coexistence and he illustrates 
If we make a determined effort to stare into the heart of the sun and turn away blinded, we see dark-colored patches before our eyes, acting as what we might call remedies. The light-image manifestations of the Apollonian mask are the inevitable products of a momentary gaze into the terrifying core of nature: light patches to heal the wounded gaze scorched by the terrible night.(74)

If illusion prevails then Dionysian world becomes self-destructive where nothing holds onto anything and a quagmire of chaos which has no ray of light. It is dark and scary if the chaos is not peeked into with some order. On the other hand if categories and binaries prevail in terms of manifestation of the reality then there is no scope for aesthetics, beauty and there is no truth in that. "Everything that we now refer to as culture, education, and civilization will one day kneel before that infallible judge, Dionysus" (Nietzsche 76) and at the same time "the Apollonian wrenches us out of Dionysian universality. With the tremendous impact of images, concepts, ethical teachings, and stirrings of sympathy, the Apollonian lifts man out of this orgiastic self-destruction" (Nietzsche 76).

Human civilization has been subjected to utter decadence, hollowness and fragmentation since they realized their power to channelize their energies towards conquering over other. The civilization has undergone a journey from peace to turmoil, from collective to individual, and from nature to personal. Auden in his "Muse de Beaux Arts" says"where the dogs go on with their doggy life" (12) while commenting on the curvature of human spirits which have become explicitly individualistic in nature. Similarly, Neruda in his "Heights of Machu Picchu" presents his deep sorrow over the denial of collectivity by the present world and he says

I wanted to swim in the broadest lives, in the openest river mouths, and as men kept denying me little by little, 
blocking path and door so I would not touch

with my streaming hands their wound of emptiness,

then I went street after street and river after river,

city after city and bed after bed,

and my brackish mask crossed through waste places,

and in the last low hovels, no light, no fire,

no bread, no stone, no silence, along,

I roamed round dying of my own death.(110-120)

Amidst such a scenario there are icons such as Che Guevara who, as Auden has said in his "Shields of Achilles", "weep because another wept" (55). The travelling account of Che Guevara is not just travelling through the lost civilization which ends with his motorcycle travel; rather it is a journey which changes its shape and dynamics into an unending sacrificial passion. His journey is from self to collective where the journey adds an angle of introspection. The flight from personal to collective has to have grounds of selfreflexivity like the one seen in Rembrandts last portrait. He through his heroic journey emphasized the rule of harmony over violence. Harmony has to be earned through collective endeavors of which Neruda speaks in almost all of his poems. The beauty of Neruda lies in his capabilities to seek love in nature where he is in complete harmony with nature. The journey from known to unknown is the same journey which Neruda leaves towards the way to paradise. Neruda wrote his journey to Machu Picchu in "Heights of Machu Picchu" where he portrays the triviality of human life, the impermanence of human life while questioning the notion of conquering over the other. A journey is in the form not in the shape and it does not seek closure while celebrating the sense of liberation. The trajectory of a journey is nonlinear just as that of a river where the boundaries cannot be measured yet have its own contours. The emphasis of collectivity portrayed by Neruda and Che Guevara through their 
own journey is correlative to the confluence of river tributaries into one where the individual is contained in the collective whose roots are very much traceable.

The journey of Che starts with youthful enthusiasm for new lands where traveling on motorcycle becomes symbolic of an adventurous vibrant energy. The intended travel through South American continent unfolds into an entirely unexpected domain where the journey within CheGuevara undergoes a shift from an adventurous spirit to maturity. Che Guevara in his The Motorcycle Diaries says that it is difficult to grasp the spirit of a place in such a less time which becomes evident in the further episodes of his journey. Che Guevara and Alberto Granado had to set off La poderosa, their motorcycle, in Santiago de Chile because of its poor condition which made them set on foot for the further journey. It is this very moment where this transition in CheGuevara's journey finds its roots. His interaction with different spaces becomes much more expansive and elaborate from now onwards and the impacts of architectural space and its interconnections with one's personality start showing its impressions. CheGuevara says after they have left behind the Argentinian soil "the photograph was an acknowledgment of our changed circumstances and of the horizons we were seeking, free at last from the civilization"(42). The route of his journey marks its way away from the civilization to which he belongs to and takes him deep into the primitive evocation of genuine emotions corresponding to humanity.

Paul Gauguin in The Way to Paradise embarks on a journey away from the European civilization and its imperial sensibility in search of purest primitive human expression. Both the journeys take a collective flight from being personal which makes Paul Gauguin enter into the realm of unadulterated natural settings of human emotions and expressions and on the other hand makes Che Guevara land up in the Leper colony in San Pablo. His pure emotions towards those who are suffering from leprosy, the way he indulges himself with them on personal level and his gesture of surpassing the division created on the basis of 
disease are all suggestive of the journey of his self. He says "journey is never sequential, it is spiritual" (56) which are exemplified through his actions.It is his journey from "I" to "we" which embodies his travelogue into a never-ending spiritual quest where he finds himself crossing the river from his camp to Leper colony on his birthday. This crossing of the river is symbolic of Che's moving beyond his individualistic travel to collective journey where he unites himself with the artist of humanity. Every revolutionary act against oppression has suffered so does Che Guevara which can be read in Don McLean's Starry Starry Night song

And now I think I know what you tried to say to me

How you suffered for your sanity

How you tried to set them free.

They would not listen

They're not

List'ning still

Perhaps they never will.

In $16^{\text {th }}$ century the European power wreaked havoc onthe newly discovered land, that is, American continents. The conquest of the South American continent and the consequent 'clash' was cataclysmic, as the socio-economic subversion is still embedded almost nonretrievably deep in terms of its collateral. The rich lands of this continent lured the European masses who, tormented by the religious tensions and depletion of resources, made their way to the continent with the hope of forming a new independent culture. Eventually they shattered their hopes with their own hands by foregrounding the same situations and turmoil from which they had run through. The account of Francisco Pizarro, the Spanish conquistador, during the conquest of Incan civilization and the impact of this event on the civilization as a collective whole traces the ethical curvature of two distinct civilizations, namely the Incan and the Christian Imperial West. 
Che Guevara's visit to the lost city of Machu Picchu is symbolic in understanding the architectural space and its influence. Machu Picchu is the central image which is the marker of a lost civilization where the distorted architecture echoes the richness and the loss at the same time. It becomes the meeting point of Spanish conquistadors, the rich Incan civilization and the havoc wrecked upon the people. The grandeur of architecture signifies that the Incan civilization was self-sufficient, self-sustained and abundant. Neruda in "Heights of Machu Picchu" places an empathizing evocation of the lost city while romanticizing the past in a glorified manner. He says

High city of laddered stones, at last the dwelling of what earth never covered in vestments of sleep. In you like two lines parallel, the cradles of lightning and man rocked in a wind of thorns.

Mother of stone, spume of condors.

High reef of the human dawn. (203-210)

On his way Che Guevara had several encounters with the indigenous people that had a tremendous impression on his outlook. He has a different persona which can be beautifully read in Faiz'snazm

mujh se pahaliisiimohabbatmeriimahabuubnamaang main ne samajhaathaakituuhai to darakhshaanhaihayaat teraa Gam hai to Gam-e-daharkaajhagadaakyaahai teriisuurat se haiaalammeinbahaaroonkosabaat teriiaankhoonkesivaaduniyaameinrakkhaakyaahai 


\author{
lautjaatiihaiudharkobhiinazarkyaakiije \\ abbhiidil_kashhaiteraahusnmaGarkyaakiije \\ aurbhiidukhhainzamaanemeinmohabbatkesivaa \\ raahateinaurbhiihainvaslkiiraahatkesivaa
}

The journey of self-reflexivity of Che brings about fundamental changes in his personality where he feels more connected with the cause of humanity. He finds himself no longer exclusive rather his outlook has undertaken a major shift from being exclusive to being inclusive. The journey unfolds itself in the transfiguration of the self and the state of being. The journey begins when the state of existence of the self comes in the state of being where the one is under transformation constantly. Faiz'snazm invokes this state of being in which the lover is moving towards the collective idea of love where his individual love surpasses and attains a sublime state. When Faiz says "mujhsepehlisimohabbatnamang" he emphasizes the transformed persona of the lover like Che who could feel the sufferings of others during his journey as "aurbhidukhhainzamaane me mohabbatkesivaa". Here he collectivize the larger humanity and the sufferings of a cause instead of framing the feeling of love in individualistic shapes.

During their expedition in Chilean countryside he found the conditions of natives have been brutalized by modern civilization. The clash of two civilizations is prominently visible in the defeated race and the manner they have been thrown at the back seat in their own lands. The tragedy in the eyes of the couple, whom Che Guevara met in mining lands, invokes this very clash where the imperial imposition and the imposed way of living have horrific effects on the natives. The European force has brutally effaced the indigenous race from the picture through religious, ideological and physical imperialism. But at the same time it is crucial to note that there is never complete overlapping of one over the other. Neruda says 
Yet a permanence of stone and word, the city like a bowl, rose up in the hands

of all, living, dead, silenced, sustained, a wall out of so much death, out of so much life a shock of stone petals: the permanent rose, the dwelling place: the glacial outposts on this Andean reef. (157-162)

Till today traces of the lost civilization are visible. Here Neruda talks about eternal significance of stones which encompasses eternal civilization its manifestation in physical form and eternal memories in ideational form. He says remembrance never goes out despite the subsequent conquering and effacing out mechanism. The idea of permanence in impermanence, much noticeable in John Keat's poem "Ode on a Grecian Urn”, exemplifies Neruda's “permanent rose" (161). This is explicit in Che's The Motorcycle Diaries where through his way to Estaque town he comes across legendary valleys, irrigations channels built by Incas, the crops cultivated by Indians and the manner of growing crops in terraces harps back to the primitive native societies. He says "The town's very breath evokes the time before Spanish colonization. But the people are a defeated race whose stares are tame, almost fearful, and completely indifferent to the outside world". He even found indigenously American peasants in Chilean countryside whose appearances and dresses signify the existence of purity of race untouched by exoticism.

The more evident fact is the amalgamation of the two civilizations and the imposition of European over the other especially in the religious space. The cathedrals of Lima and Cuzco depict the imposition and the clash. Cuzco was the original capital of the Inca city which was destroyed and crudely reformed by the colonizers whereas the reformation of Lima, which they made the new capital, is somewhat stylized through the imported European art. Lima represents the typical Spanish colony with its colonial church and culture whereas 
Cuzco is evocative where there are strong echoes of destruction, imposition, and nativity in its architecture. Certain cultural practices of such areas represent the amalgamation of the two such as religious practice at Pachamama where natives used to worship the symbolic form of a stone-shape of pyramid. Spaniards, when they failed to destroy the belief, placed a cross atop each pile of stone. It appears to be that the lost tradition of lost civilization is still in practice but with the re/vision of the conquistadors.

CheGuevara said we will make human beings of $21^{\text {st }}$ century, we ourselves; Neruda the poet captures the trajectory and curvature as they echo and reverberates from the heights of Machu Picchu

Give me silence, water, hope.

Give me struggle, iron, volcanoes.

Fasten your bodies to me like magnets.

Hasten to my veins to my mouth.

Speak through my words and my blood. (400-405) 


\section{Works Cited}

Auden, Wystan Hugh. Collected Poems. London: Vintage International, 2007.

Battacharya. Faiz. India: Rajkamal Prakashan Pvt. Limited, 2010.

Gogh, Vincent Van. Starry Night Over the Rone. 1888. Oil on Canvas. Musee d'Orsay. Paris.

Guevara, Ernesto Che. The Motorcycle Diaries. London: HarperCollins Publisher, 2004.

Keats, John. John Keats: The Complete Poems. Penguin Classics, 1977.

MacLean, Don. "Starry Starry Night. ”American Pie, Songs of Universal Inc., 1971.The Van Gogh gallery, www.vangoghgallery.com/painting/starrynightlyrics.html.

Neruda, Pablo. Heights of Macchu Picchu. Chile: Farrar, Straus and Giroux, 1967.

Nietzsche, Friedrich. Trans Shaun Whiteside. The Birth of Tragedy. Penguin Classics, 2003.

The Motorcycle Diaries. Dir. Walter Salles. USA, 2004. 